\title{
Management of Cooling Water Chemistry of Wet Cooled Power Plants in South Africa
}

\author{
L.L. Sibiya, G. Gericke, F. Waanders and E. Fosso-Kankeu
}

\begin{abstract}
Scaling, fouling and corrosion are known to have a substantial effect on the performance of coal fired power plant condensers. There are different treatment processes employed in combination with the in-service mechanical cleaning, however, the treatment processes have some limitations when looking at the cooling water chemistry control and condenser efficiency.

The main purpose and focus of the study will be to understand the different treatment process limitations, constrains and optimization parameters. Conditions under which scaling, fouling and corrosion occur will be predicted using the Calcium Carbonate Precipitation Potential (CCPP) index to effectively treat, mitigate and minimise the challenges. CCPP is the calculated mass of calcium carbonate expected to precipitate or be dissolved by water.

Coal fired power plants with the desalination process implemented will have better cooling water chemistry control compared to those using a cooling water treatment approach based on neutralisation, clarification through flocculation and coagulation, cold lime softening, ion exchange and blowdown method. With the exception of the cold lime soda treatment, some of the treatment processes are costly and generate concentrated effluents that must be disposed.

It is predicted that, cold lime treatment when operated optimally may yield positive results and can therefore be considered as treatment of choice for the control of the cooling water chemistry.
\end{abstract}

Keywords: CCPP, cooling water chemistry, scaling, fouling and corrosion, wet cooled coal power plant.

\section{INTRODUCTION}

The largest percentage of electricity in the world today is produced in the steam cycle using fossil fuels as the energy source, to convert water to steam to drive turbines which in turn drive generators.

Condensers are the largest heat exchangers in power plants, where the steam flowing from the low-pressure part of the steam turbine is condensed using cooling water [1].

Manuscript received October 1, 2019. This work was supported in part by Komati Power Station Chemical Services Department and Eskom Power Plant Engineering Institute

L.L Sibiya is with School of Chemical and Minerals Engineering,

North-West University, Potchefstroom, South Africa.

G. Gericke is with Eskom Research Testing and Development

E. Fosso-Kankeu is with the Water Pollution Monitoring andRemediation Initiatives Research Group, School of Chemical and Minerals Engineering, Faculty of Engineering, North-West University, South Africa

F. Waanders is with the Water Pollution Monitoring and Remediation Initiatives Research Group, School of Chemical and Minerals Engineering, Faculty of Engineering, North-West University, South Africa.
The main cooling system serves as the cooling medium for the electricity generating systems. Cooling water system for different power plants have a water capacity ranging between 25 to 47 Mega Litre (ML), which takes up the largest portion of water used in the power plant, thus proper treatment is very essential [2]. The steam form the turbine condenses in the condenser and the latent heat [3] of condensation is absorbed by the cooling water [4].

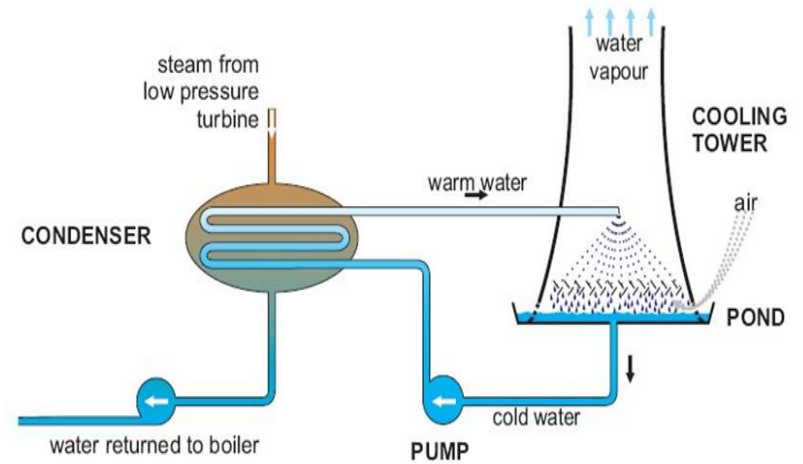

Fig. 1: Simple schematic diagram showing of cooling water circuit [5]

In order to achieve a higher thermal efficiency of the steam cycle process, condensation must be at low pressure, which primarily depends on the conditions of the cooling water. Circulating cooling water quality requirements are related to three major problems encountered, scaling, fouling and corrosion [6].

These problems capably insulate the heat transfer system tube wall. The effects of the reduction in heat transfer are an increased pressure drop, increased pumping power requirements and the reduction of the power output in the components [7].

The changes in the cooling water chemistry affects the characteristics which describes the condenser performance, such as efficiency, the transfer net flow and the steam back pressure which have a significant influence on the performance of the plant [8].

To address the scaling, fouling and corrosion challenges, diverse softening processes are being employed. There are set chemistry monitoring standards guided by the Electrical Power Research Institute (EPRI) [5] and Vereinigung Der Grosskraftwerksbetreiber (VGB).

These standards have limits and targets for cooling water monitoring and control, but achieving these limits have been almost impossible on some of the operating plants due to 
challenges experienced in the cooling water softening treatment processes.

As the chemistry on the cooling water system deteriorates [8] the softening plant needs to treat the water to reduce the hardness.

The existing treatment processes are struggling to maintain the cooling water chemistry within specifications as governed by the cooling water chemistry standards [4-9].

This is due to the challenges that are currently being experienced in operating and optimising the treatment plant, affected by makeup water quality fluctuations and more effluent being generated by power plants and must be recovered [10].

Condenser chemical cleaning is conducted more frequently due to, scaling, fouling, and corrosion found on the heat transfer equipment [11-13]

Condenser tube leaks are also increasing in number leading to reduced condenser efficiency and automatically impacting on the electricity generation by shutting down of the plant for maintenance and repairs. [11-13]

The optimum process for cooling water chemistry control will be the process that effectively controls the cooling water chemistry and allow cycles of concentration $(\mathrm{CoC})$ that will ensure Zero Liquid Effluent Discharge (ZLED) [14]; therefore, allowing the power utility to minimize its footprint and reduce the pressure on the limited water resource of the country [15-38].

\section{POWER PLANT COOLING WATER CHEMISTRY}

Coal fired power plants are designed with different treatment process to control by softening and mitigate the degradation of cooling water systems. The treatment process can be divided into three main categories: those that affect solubility,

those that alter the growth mechanism of crystals, and those that change the potential of a surface to foul [7] Each of these controls have their benefits and a number of aspects have to be considered during the design phase and selecting the right preference [7].

It is desirable to predict conditions under which scaling, fouling and corrosion occur based on known system conditions.

In this way problems can be evaded, minimised or more effectively managed [7]

\section{Treatment processes employed for cooling water softening}

\section{A. Clarification through coagulation and flocculation}

The clarification coagulation and flocculation process is required for the removal of colloidal/suspended matter. At high cycles of concentration (CoC), the suspended matter created by coarse and finely dispersed impurities [7] tends to settle in the cooling tower ponds, thus reduce the pond capacity and cooling water volume.

The cooling water pumps will take suction from the pond and transfer the sludge to the condenser tubes. Under clean conditions the pumps will only be exposed to water, with the sludge settling at the bottom of the pond the pumps will be exposed to water and sludge. This will lead to erosion, fouling and/or under deposit corrosion [39].

The consequence of this is a reduction in cross sectional area, significant pressure drop along with a deterioration in the heat transfer capacity [7]. These suspended particles will also settle in the condenser tubes and create a lump that will reduce the efficiency of heat transfer. This treatment process gives the water its esthetical appearance.

\section{B. Softening with lime and soda ash for the removal of permanent and non-permanent harness (scaling products)}

Lime treatment is often used to reduce the bicarbonate hardness by precipitation of cooling water and to enhance clarification. The bicarbonate hardness due to calcium and magnesium multivalent ions [7].

The higher the $\mathrm{CoC}$, the more the total dissolved solids (TDS) will increase as the salts are gradually increasing in concentration. With an increase in the $\mathrm{CoC}$ the Calcium Carbonate Precipitation Potential (CCPP) will also increase.

The CCPP target given in the EPRI and VGB cooling water guideline can be calculated using the "stasoft model", a friendly interactive computer model [13]. CCPP specification without the crystal modifier dosing is between 10 and $30 \mathrm{mg} \cdot \mathrm{kg}^{-1}$ as $\mathrm{CaCO}_{3}$ at $38^{\circ} \mathrm{C}$. With a crystal modifier dosing the target is set between 10 and $45 \mathrm{mg} \cdot \mathrm{kg}^{-1}$ as $\mathrm{CaCO}_{3}$ at $38^{\circ} \mathrm{C}$.

The efficiency of the softening reactions is greatly influenced by temperature and ionic strength [40]. Higher temperatures accelerate the reaction rate and permits the reactions to be carried out at lower $\mathrm{pH}$ 's. Inversely higher ionic strength reduce ion activities and ion pairs are created that do not participate in the softening process [41].

There are two critical criteria needed for proper softening of cooling water using lime treatment:

1. Treatment should be done at an optimal $\mathrm{pH}$, and

2. Correct volumes of cooling water must be treated

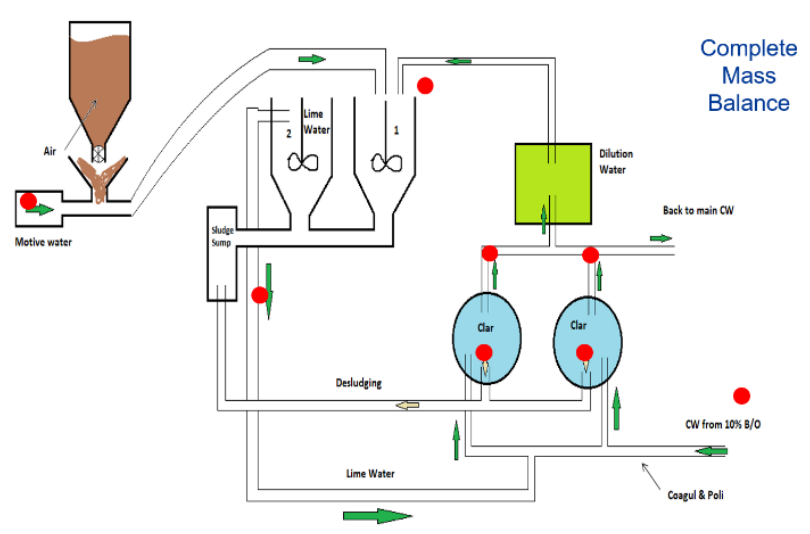

Fig. 2. Lime dosing plant layout [5]

Firstly: Optimum $\mathrm{pH}$ during the softening of the cooling water is essential to convert all bicarbonate in the main system to carbonates

To achieve the optimal $\mathrm{pH}$, calcium hydroxide (lime) is introduced to the cooling water that goes in to the clarifier. The optimum $\mathrm{pH}$ for the lime softening process is 10.1 to 10.3 according to [42], though it can vary based on plant specifications and operations.

Removal of carbonate hardness: 
The conversion of dissolved calcium hydrogen carbonate in to calcium carbonate can be described by: [43]

$$
\mathrm{Ca}\left(\mathrm{HCO}_{3}\right)_{2}+\mathrm{Ca}(\mathrm{OH})_{2} \rightarrow 2 \mathrm{CaCO}_{3} \downarrow+2 \mathrm{H}_{2} \mathrm{O}
$$

Removal of carbon dioxide in a closed system

$$
\mathrm{CO}_{2}+\mathrm{Ca}(\mathrm{OH})_{2} \rightarrow \mathrm{CaCO}_{3} \downarrow+2 \mathrm{H}_{2} \mathrm{O}
$$

For water with a high proportion of magnesium hydrogen carbonate

$$
\mathrm{Mg}\left(\mathrm{HCO}_{3}\right)_{2}+\mathrm{Ca}(\mathrm{OH})_{2} \rightarrow \mathrm{CaCO}_{3} \downarrow+\mathrm{MgCO}_{3}+2 \mathrm{H}_{2} \mathrm{O}
$$

Since magnesium carbonate is soluble excess line is added to precipitate it as magnesium hydroxide

$$
\mathrm{MgCO}_{3}+\mathrm{Ca}(\mathrm{OH})_{2} \rightarrow \mathrm{CaCO}_{3} \downarrow+\mathrm{Mg}(\mathrm{OH})_{2}
$$

Secondly: Not treating the correct volume of water for the system, even at optimum $\mathrm{pH}$, the scaling might still occur. Treating the correct volume means the same amount of alkalinity is removed in the clarifiers as to what is added to the cooling water through make up.

This can be achieved by proper flow measurement for the water going to the clarifier's. Inconsistency in flow measurements will exposed the plant to incorrect lime dosing rates, thus causing an increase in the scaling potential.

These two criteria must be equally met, to minimize and prolong scaling potential on the condensers.

\section{Softening by Neutralisation/pH control}

As the potential to form carbonate scale is $\mathrm{pH}$ dependent, a simple way to control scale or precipitate formation is to control the $\mathrm{pH}$. The use of inorganic acids such as sulphuric and hydrochloric acid or organic acids such as citric acids, as $\mathrm{pH}$ adjusters is extensive [8]. The $\mathrm{pH}$ control takes place through the dosing of acid to reduce the $\mathrm{pH}$. The acid reacts with the carbonates and hydroxides that are present in the water yielding water and $\mathrm{CO}_{2}$. This prevents the formation of calcium carbonate and magnesium hydroxide scale [44]. The concern is the ions that will normally remain insoluble in water

Common acids used are sulphuric and hydrochloric acid

$$
\begin{aligned}
& \mathrm{Ca}\left(\mathrm{HCO}_{3}\right)_{2}+2 \mathrm{HCl} \rightarrow \mathrm{CaCl}_{2}+2 \mathrm{CO}_{2}+2 \mathrm{H}_{2} \mathrm{O} \\
& \mathrm{Ca}\left(\mathrm{HCO}_{3}\right)_{2}+\mathrm{H}_{2} \mathrm{SO}_{4} \rightarrow \mathrm{CaSO}_{4}+2 \mathrm{CO}_{2}+2 \mathrm{H}_{2} \mathrm{O}
\end{aligned}
$$

\section{Softening by desalination}

Desalination is a pressure based driven membrane process [45]. The leading process for desalination in terms of installed capacity and yearly growth is Reverse Osmosis (RO). RO membrane processes use semipermeable membranes and applied pressure (on the membrane feed side) to preferentially induce water permeation through the membrane while rejecting salts. Energy cost in desalination processes varies considerably depending on water salinity, plant size and process type.

\section{E. Using scale inhibitors}

Scale inhibitors are a group of speciality chemicals that are used to prolong and prevent scaling in water systems [46].

They do not eradicate the component of scale but prevents crystal nucleation and crystal growth. Nucleation is the initial process that occurs in the formation of a crystal from a solution, a liquid, or a vapor, in which a small number of ions, atoms, or molecules become arranged in a pattern characteristic of a crystalline solid, forming a site upon which additional particles are deposited as the crystal grows [47-49].

An understanding on the type/nature of the feed water that must be inhibited, the composition/characteristics of the water, the concentration of inorganic salts, conditions of the industrial operations and the nature of operations is required.

\section{METHODOLOGY}

Power plants where wet cooled condensers are in use and preferably those with the highest cooling water out of specification chemistry were sampled and evaluated.

Cooling water chemistry data for the past years from the Laboratory Information Management System (LIMS) [50] [51] plotted and analysed to understand the cooling water chemistry behaviour from sampled power plants.

Scale and corrosion potential index Calcium Carbonate Precipitation Potential (CCPP) calculated to observe differences in plant performance for concentrated cooling water chemistry control, using three different treatment processes (cold lime softening, neutralization treatment and desalination cooling water treatment).

CCPP is an acronym that stands for Calcium Carbonate Precipitation Potential. It is the calculated mass of calcium carbonate expected to precipitate or be dissolved by particular water. It is expressed as milligrams per litre $(\mathrm{mg} / \mathrm{L})$ calcium carbonate $\left(\mathrm{CaCO}_{3}\right)$ [52-53].

CCPP of the cooling water calculated using the stasoft software, parameters of concern being, calcium hardness, $\mathrm{pH}$, conductivity, alkalinity analysed by an autotitrator, chlorides and sulphates analysed by the IC (Ion Chromatography) instrument and sodium analysed using the ICP (Inductively Coupled Plasma) spectroscopy.

Operating philosophies at the treatment plants, current Standard Operating Procedures (SOP) and any deviations with reasons and the limitations on the treatment processes reviewed.

\section{RESULTS AND RECOMMENDATION}

Scaling potential indices have been developed to predict the likelihood of calcium carbonate precipitation. These indices are convenient, easy to use, and provide a reasonable estimate of the likelihood of scaling in water sources. The most widely used indices in the water treatment industry are the Langelier

Saturation Index (LSI), Stiff and Davis Stability Index (S\&DSI), the Ryznar stability index, and the Larson-Skold Index.

The Calcium Carbonate Precipitation Potential (CCPP) is preferred although more complicated to calculate $[52,53]$.

Scaling potential indices are only capable of predicting the potential or propensity of a water to form scale or corrode. CCPP is a qualitative indicator it does not indicate the extend of precipitation.

CCPP (along with other indexes such as LSI) is also used to assist in chemical dosing rates to ensure water in the 
distribution system will not corrode metal or dissolve concrete pipes, guided by the table below:

TABLE I: CCPP INTERPRETATION [54]

\begin{tabular}{|l|l|}
\hline Scaling state of water & CCPP mg/l $\mathbf{C a C O}_{\mathbf{3}}$ \\
\hline Scaling & Greater than 0 \\
\hline Passive & Between 0 and -5 \\
\hline Mildly corrosive & Between -5 to -10 \\
\hline Corrosive (aggressive ) & Less than -10 \\
\hline
\end{tabular}

A. Cold lime treatment process

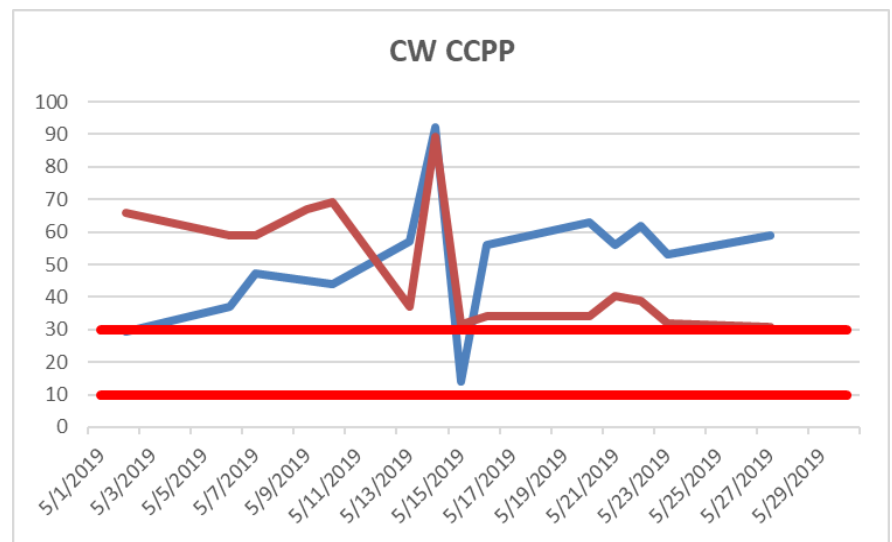

Fig. 3 CCPP calculations using cold lime treatment

As lime is added to the water the $\mathrm{pH}$ and the equilibrium of carbonate species in the water is shifted. Dissolved carbon dioxide is changed in to bicarbonates then carbonates. This causes calcium carbonate to precipitate due to exceeding the solubility product.

It can be observed from the results (Fig 3) that the CCPP is always on the scaling side. There is no indication of the high corrosive rates.

The results indicate that too much lime has been added, though the conversion of bicarbonates to carbonates is complete there is a formation of additional hydroxide ions.

The hydroxide ions will react with the carbon dioxide in the atmosphere to form bicarbonates that will form calcium carbonate scale in the heat exchanger. CCPP above the limit will expose the heat exchangers to scaling.

This is an undesired condition, addition to the scaling issues, $\mathrm{CoC}$ will increase and more blow downs will be required.

\section{B. Neutralisation treatment/pH correction}

The potential to form calcium carbonate scales is $\mathrm{pH}$ dependent, a simple way to control scale or precipitate formation is to control the $\mathrm{pH}$. For the purpose of the study the sulphuric acid as the most common $\mathrm{pH}$ control agent was considered.

From the results it can be observed that there is a potential of maintaining CCPP within the limits. Challenges are experienced when there are changes in the cooling water chemistry due to make up or several sources that are blended for cooling water make up.

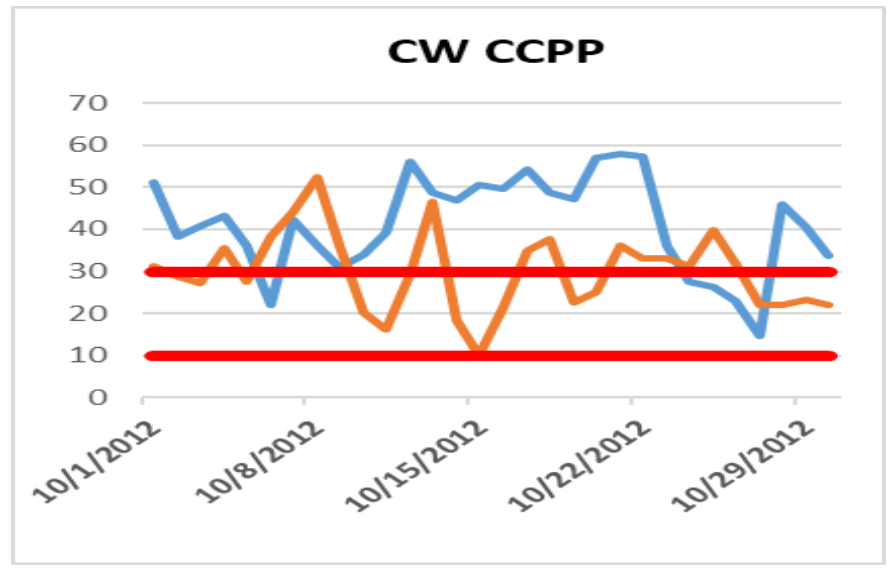

Fig. 4. CCPP calculation using neutralization treatment

The reason for the CCPP fluctuations is due to the composition of the makeup water that changes. The system is not automated to acknowledge the changes and adjust the acid dosing accordingly. Manual interventions are required to overcome the change and that makes the operation and management of the treatment process to depend on human interventions. With the chemistry changing frequently there is always a delayed response

Neutralisation treatment process is the simplest treatment regime; the key is to keep the $\mathrm{pH}$ adjustment within the control limits. Another limitation will be to manage the potential of exceeding calcium sulphate solubility and start forming calcium sulphate scaling.

\section{Desalination treatment process}

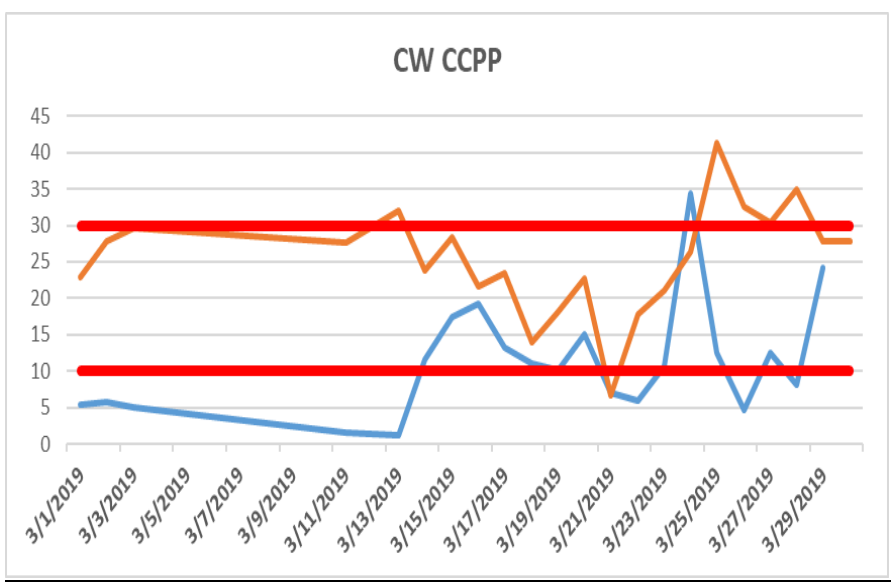

Fig.5. CCPP calculation using desalination by Reverse Osmosis

The best cooling water quality is achieved by desalination as seen from Fig 5. CCPP is mostly within required cooling water chemistry standard limits. This could easily be regarded as the best treatment of choice.

Desalinating water through membrane filtration including reverse osmosis (RO) is gaining popularity. RO requires forcing the cooling water through progressively smaller membranes resulting in a lot of energy for pumping, this process obviously requires a lot of heat energy. There are additional issues with the incoming and outgoing water and effluent generated. 
Solutions for a more efficient integrated industrial water use and management depend on their economical evaluation and on external drivers.

\section{CONCLUSION}

The study compared three different treatment processes for cooling water softening from three sites. The parameter of concern was the Calcium Carbonate Precipitation Potential (CCPP), referred as the calcium solubility equilibrium. CCPP which is directly associated with scale formation and a quick indicator to show if the plant is exposed or protected

The following conclusions can be drawn from the results.

\section{A. Cold lime treatment}

Given proper consideration of raw water quality and ultimate end use of the treated water, the application of cold lime treatment process has few limitations, however, operational difficulties may be encountered for example temperature variations, chemical dosing control, rapid flow variations etc.

The cold lime treatment process has a significant potential advantage as a method for application to treatment of recycled cooling water. From the results CCPP exceeds the specification limits almost all the time.

There are different parameters manipulated to achieve the chemistry objective, $\mathrm{CW}$ flow rate, lime dosing rate, retention time, clarifier de- sludge rate, to name a few. Very close supervision of the operation is required to reduce the carbonate hardness to ensure proper cooling water treatment control

The advantages of lime treatment include a lower water consumption and an improved water balance. Carbonate hardness can be reduced to practically the theoretical limits irrespective of the temperature.

\section{B. Neutralisation}

It can be observed from Fig 2 that the CCPP exceeds the specification values almost all the time. Dosing of sulphuric acid to the main cooling water stream has negative consequences whereby it increases the sulphate concentration requiring additional blow downs as the sulphate ion will be the limiting ion in terms of concentrations. More than usual blow downs require more frequent cooling tower make-up, thus increased costs.

When sulphuric acid is utilized for alkalinity and $\mathrm{pH}$ control, it is essential that the acid is dosed on a continuous basis. Slug dosing of acid which causes major drops in alkalinity followed by equivalent increases in alkalinity which must be avoided. Such operations result in alternate corrosive conditions followed by scale forming conditions.

\section{Desalination Treatment Process}

The reverse osmosis process comes with extreme maintenance costs. Numerous factors interfere with efficiency of the process for example, ionic contamination (calcium, magnesium etc), Dissolved Oxygen Carbon (DOC), bacteria, viruses, colloids, and insoluble particulates, biofouling and scaling.

In extreme cases, the RO membranes are severely damaged. To lessen the damage, various pre-treatment stages are presented. Anti-scaling inhibitors including acids and other agents such as the organic polymers, polyacrylamide and polymaleic acids phosphonates and polyphosphates. Inhibitors for fouling are biocides (as oxidants against bacteria and viruses), such as chlorine, ozone, sodium or calcium hypochlorite.

At regular intervals, depending on the membrane contamination, fluctuating cooling water conditions, or when prompted by monitoring processes, the membranes need to be cleaned, known as cleaning in place (CIP) or shock-flushing. Cleaning and flushing is done with inhibitors or CIP chemicals in a fresh water solution and the plant must go offline.

The results indicate that desalination is the best treatment of choice for cooling water treatment but all the variables including operating and maintenance constrains must be taken in to consideration. It is costly and does generate other waste streams that needs to be handled in the later stage.

At present the cost of cooling water treatment is higher, but it is expected that costs will continue to decrease with technology improvements that will include, but are not limited to, improved efficiency, reduction in plants footprint, improvements to plant operation and optimization, more effective feed pre-treatment, and lower cost energy sources.

$$
[54,55]
$$

\section{ACKNOWLEDGMENT}

Credits. The authors are grateful to the sponsor from Eskom Komati Power Station and the Eskom Power Plant Engineering Institute. Any opinions, findings and conclusions or recommendations expressed in the material are those of the authors and therefore Eskom does not accept any liability in regard thereto.

\section{REFERENCES}

[1] Ryznar, J.W., 1944. A new index for determining amount of calcium carbonate scale formed by a water. Journal-American Water Works Association, 36(4), pp.472-483.

https://doi.org/10.1002/j.1551-8833.1944.tb20016.x

[2] Touir, R., Dkhireche, N., Touhami, M.E., Lakhrissi, M., Lakhrissi, B. and Sfaira, M., 2009. Corrosion and scale processes and their inhibition in simulated cooling water systems by monosaccharides derivatives: Part I: EIS study. Desalination, 249(3), pp.922-928. https://doi.org/10.1016/j.desal.2009.06.068

[3] Zhai, H. and Rubin, E.S., 2010. Performance and cost of wet and dry cooling systems for pulverized coal power plants with and without carbon capture and storage. Energy Policy, 38(10), pp.5653-5660. https://doi.org/10.1016/j.enpol.2010.05.013

[4] Seyrig, G. and Shan, W., 2007. Chemical precipitation: water softening. ENE, 806

[5] McElrath, J., EPRI Technical report 2012. Open Cooling Water Chemistry Guideline

[6] Ouyang, X., Qiu, X., Lou, H. and Yang, D., 2006. Corrosion and scale inhibition properties of sodium lignosulfonate and its potential application in recirculating cooling water system. Industrial \& engineering chemistry research, $45(16)$, pp.5716-5721. https://doi.org/10.1021/ie0513189

[7] MacAdam, J. and Parsons, S.A., 2004. Calcium carbonate scale formation and control. Re/Views in Environmental Science \& Bio/Technology, 3(2), pp.159-169. https://doi.org/10.1007/s11157-004-3849-1

[8] Cho, Y.I., Lee, S., Kim, W. and Suh, S., 2003. Physical water treatment for the mitigation of mineral fouling in cooling-tower water applications.

[9] McCoy, J.W., 1974. The chemical treatment of cooling water (p. 112). New York: Chemical Publishing Company.

[10] Mkabane, P.T., 2015. Effluent treatment and its re-use for the Kriel Power Station (Doctoral dissertation, North-West University (South Africa), Potchefstroom Campus). 
[11] Sinha, A.K., 2010. Aspects of failure of condenser tubes and their remedial measures at power plants. AKS/Journal.

[12] Joshi, H.M. and Brons, G., 2003. Chemical Cleaning of Oil Refinery Heat Exchangers--The Need for a Joint Effort.

[13] Kintner, E.K., Kintner Edwin K, 1980. Condenser cleaning system using sponge balls. U.S. Patent 4,234,993.

[14] Matson, J.V. and Harris III, T.G., 1979. Zero discharge of cooling water by sidestream softening. Journal (Water Pollution Control Federation), pp.2602-2614.

[15] Elvis Fosso-Kankeu. 2019. Nano and Bio-based Technologies for wastewater treatment: Prediction and Control Tools for the dispersion of Pollutants in the Environment. Wiley Scrivener. ISBN: 978-1-119-57709-6. Pp 301-336.

[16] Elvis Fosso-Kankeu. 2019. New Horizons in Wastewaters Management: Emerging Monitoring and Remediation Strategies. Nova Science Publishers. ISBN: 978-1-53615-659-1.

[17] J.G. Redelinghuys, E. Fosso-Kankeu, G. Gericke, F. Waanders. 2019 Coal Power Plant Wastewater Treatment by Thermal and Membrane Technologies. In Nano and Bio-based Technologies for wastewater treatment: Prediction and Control Tools for the dispersion of Pollutants in the Environment. Editor: Elvis Fosso-Kankeu. Wiley Scrivener. ISBN: 978-1-119-57709-6. Pp 149-168. https://doi.org/10.1002/9781119577119.ch5

[18] N. Mukwevho, E. Fosso-Kankeu, F. Waanders. 2019. PAHs Released from Coal Tars and Potential Removal Using Nanocatalysts. In Nano and Bio-based Technologies for wastewater treatment: Prediction and Control Tools for the dispersion of Pollutants in the Environment. Editor: Elvis Fosso-Kankeu. Wiley Scrivener. ISBN: 978-1-119-57709-6. Pp 169-203. https://doi.org/10.1002/9781119577119.ch6

[19] Corli de Klerk,Elvis Fosso-Kankeu and Frans Waanders. 2019. Nanoparticle-biopolymer antimicrobial compounds as sustainable option for wastewater treatment. In New Horizons in Wastewaters Management: Emerging Monitoring and Remediation Strategies. Editor: Elvis Fosso-Kankeu. Nova Science Publishers. ISBN: 978-1-53615-659-1.

[20] Fosso-Kankeu E., Potgieter J. and Waanders F.B. 2019. Removal of malachite green and toluidine blue dyes from aqueous solution using a clay-biochar composite of bentonite and sweet sorghum bagasse. International Journal of Applied Engineering Research. 14(6): 1324-1333.

[21] Johannes Cornelius van der Linde, Elvis Fosso-Kankeu, Gerhard Gericke, Frans Waanders, Louise Dreyer, Nico Lemmer. 2019. Flocculant types and operating conditions influencing particles settling rates in feed water used at a coal power plant. Desalination and Water Treatment. 150: 293-300. https://doi.org/10.5004/dwt.2019.23735

[22] Erdogan IC, Fosso-Kankeu E, Ntwampe SKO, Waanders FB, Hoth N, Rand A, Farrar TJ. 2019. Households water quality in O'kiep - South Africa and community perception of related health risks. 167(2019): 145-155. https://doi.org/10.5004/dwt.2019.24576

[23] E. Fosso-Kankeu, P. Jagals, H. Du Preez, Exposure of rural households to toxic cyanobacteria in container-stored water. Water SA, Vol. 34, no. 5, pp. 631-636, 2008. https://doi.org/10.4314/wsa.v34i5.180660

[24] E. Fosso-Kankeu, A. Mulaba-Bafubiandi, B.B. Mamba, T.G. Barnard, Mitigation of $\mathrm{Ca}, \mathrm{Fe}$, and $\mathrm{Mg}$ loads in surface waters around mining areas using indigenous microorganism strains. Journal of Physics and Chemistry of the Earth, Vol. 34, pp. 825-829, 2009. https://doi.org/10.1016/j.pce.2009.07.005

[25] E. Fosso-Kankeu, H. Du Preez, P. Jagals, The health implication of relationships between bacterial endotoxin, cyanobacteria, coliforms and water stored in domestic containers of rural households in South Africa. Journal of Water and Health, Vol. 8, no. 4, pp. 601-610, 2010. https://doi.org/10.2166/wh.2010.094

[26] E. Fosso-Kankeu, A. Mulaba-Bafubiandi, B.B. Mamba, L. Marjanovic, T.G. Barnard, A comprehensive study of physical and physiological parameters that affect biosorption of metal pollutants from aqueous solutions. Journal of Physics and Chemistry of the Earth, Vol. 35, pp. $672-678,2010$ https://doi.org/10.1016/j.pce.2010.07.008

[27] E. Fosso-Kankeu, A.F. Mulaba-Bafubiandi, B.B. Mamba and T.G. Barnard, Prediction of metal-adsorption behaviour in the remediation of water contamination using indigenous microorganisms. Journal of Environmental Management. Vol. 92, no. 10, pp. 2786-2793, 2011. https://doi.org/10.1016/j.jenvman.2011.06.025
[28] E. Fosso-Kankeu, F. Waanders, E. Maloy, Copolymerization of ethyl acrylate onto guar gum for the adsorption of $\mathrm{Mg}$ (II) and $\mathrm{Ca}$ (II) ions. Desalination and Water Treatment. doi: 10.1080/19443994.2016.1165147: pp. 1-10, 2016.

[29] E. Fosso-Kankeu, F. Waanders, C.L. Fourie, Adsorption of Congo Red by surfactant-impregnated bentonite clay. Desalination and Water Treatment. doi: 10.1080/19443994.2016.1177599: pp. 1-9, 2016.

[30] E. Fosso-Kankeu, A. Webster, I.O. Ntwampe, F.B. Waanders, Coagulation/flocculation potential of polyaluminium chloride and bentonite clay tested in the removal of methyl red and crystal violet. Arabian Journal for Science and Engineering. DOI 10.1007/s13369-016-2244-x. 2016.

[31] A. Manyatshe, E. Fosso-Kankeu, D. van der Berg, N. Lemmer, F. Waanders, H. Tutu, Metal retention potential of sediment and water quality in the Mooi River, South Africa. Desalination and Water Treatment. doi: 10.5004/dwt2017.20222. 2017.

[32] E. Fosso-Kankeu, A. Manyatshe, F. Waanders, Mobility potential of metals in acid mine drainage occurring in the Highveld area of Mpumalanga Province in South Africa: Implication of sediments and efflorescent crusts. International Biodeterioration and Biodegradation. Vol. 119, pp. 661-670, 2017.

https://doi.org/10.1016/j.ibiod.2016.09.018

[33] E. Fosso-Kankeu, H. Mittal, F. Waanders, S.S. Ray, Thermodynamic properties and adsorption behaviour of hydrogel nanocomposites for cadmium removal from mine effluents. Journal of Industrial and Engineering Chemistry. Vol. 48, pp. 151-161, 2017. https://doi.org/10.1016/j.jiec.2016.12.033

[34] E. Fosso-Kankeu, F.B. Waanders, F.W. Steyn, Removal of $\mathrm{Cr}(\mathrm{VI})$ and $\mathrm{Zn}$ (II) from an aqueous solution using an organic-inorganic composite of bentonite-biochar-hematite. Desalination and Water Treatment. Vol. 59, pp. 144-153, 2017. https://doi.org/10.5004/dwt.2017.0059

[35] A. Manyatshe, E. Fosso-Kankeu, D. van der Berg, N. Lemmer, F. Waanders, H. Tutu, Dispersion of inorganic contaminants in surface water in the vicinity of Potchefstroom. Physics and Chemistry of the Earth. Vol. 100, pp. 86-93, 2017. https://doi.org/10.1016/j.pce.2017.04.008

[36] C. de Klerk, E. Fosso-Kankeu, F.B. Waanders, Evaluation of the antibacterial activity of metal impregnated multi-walled carbon nanotubes: impact of domestic wastewater as supporting medium. Desalination and Water Treatment.Vol. 99, pp. 272-281, 2017. https://doi.org/10.5004/dwt.2017.21735

[37] A. Manyatshe, E. Fosso-Kankeu, D. van der Berg, N. Lemmer, F. Waanders, H. Tutu, Metal speciation in the rivers around Potchefstroom based on seasonality. Water Environment Research. Vol. 90, no. 1, pp. 84-95, 2018. https://doi.org/10.2175/106143017X15054988926587

[38] L.P. Simelane, E. Fosso-Kankeu, P. Njobeh, S. Pandey, Response of bacterial biosorbents to chemical treatment as influenced by cell membrane structure and impact on the adsorption behaviour of dyes. Current Science. Vol. 114, no. 4, pp. 826-834, 2018. https://doi.org/10.18520/cs/v114/i04/826-834

[39] Jović, M., Laković, M. and Banjac, M., 2018. Improving the energy efficiency of a $110 \mathrm{MW}$ thermal power plant by low-cost modification of the cooling system. Energy \& Environment, 29(2), pp.245-259. https://doi.org/10.1177/0958305X17747428

[40] Li, H., Chien, S.H., Hsieh, M.K., Dzombak, D.A. and Vidic, R.D., 2011. Escalating water demand for energy production and the potential for use of treated municipal wastewater. https://doi.org/10.1021/es1040305

[41] Loewenthal, R.E., Ekama, G.A. and Marais, G., 1988. STASOFT: A user-friendly interactive computer program for softening and stabilisation of municipal waters. Water S. A., 14(3), pp.159-162.

[42] Water Quality and Treatment, Sixth Edition James K Edzwald

[43] Maree, J.P., 2006. Treatment of industrial effluents for neutralization and sulphate removal (Doctoral dissertation, North-West University).

[44] Rabas, T.J., Panchal, C.B., Sasscer, D.S. and Schaefer, R., 1991. Comparison of power-plant condenser cooling-water fouling rates for spirally-indented and plain tubes. In Fouling and enhancement interactions.

[45] Choudhury, M.R., Hsieh, M.K., Vidic, R.D. and Dzombak, D.A., 2012. Corrosion management in power plant cooling systems using tertiary-treated municipal wastewater as makeup water. Corrosion Science, 61, pp.231-241. https://doi.org/10.1016/j.corsci.2012.04.042 
[46] Farahani, M.H.D.A., Borghei, S.M. and Vatanpour, V., 2016. Recovery of cooling tower blowdown water for reuse: The investigation of different types of pretreatment prior nanofiltration and reverse osmosis. Journal of Water Process Engineering, 10, pp.188-199.

https://doi.org/10.1016/j.jwpe.2016.01.011

[47] Rebhun, M. and Engel, G., 1988. Reuse of wastewater for industrial cooling systems. Journal (Water Pollution Control Federation), pp. 237-241

[48] Bergles, A.E. and Somerscales, E.F.C., 1995. The effect of fouling on enhanced heat transfer equipment. Journal of Enhanced Heat Transfer, 2(1-2). https://doi.org/10.1615/JEnhHeatTransf.v2.i1-2.170

[49] Touir, R., Dkhireche, N., Touhami, M.E., Lakhrissi, M., Lakhrissi, B. and Sfaira, M., 2009. Corrosion and scale processes and their inhibition in simulated cooling water systems by monosaccharides derivatives: Part I: EIS study. Desalination, 249(3), pp.922-928. https://doi.org/10.1016/j.desal.2009.06.068

[50] Voegele, C., Tavtigian, S.V., De Silva, D., Cuber, S., Thomas, A. and Le Calvez-Kelm, F., 2007. A Laboratory Information Management System (LIMS) for a high throughput genetic platform aimed at candidate gene mutation screening. Bioinformatics, 23(18), pp.2504-2506. https://doi.org/10.1093/bioinformatics/btm365

[51] Hancock, J.M., 2004. Laboratory Information Management System (LIMS). Dictionary of Bioinformatics and Computational Biology. https://doi.org/10.1002/9780471650126.dob0385.pub2

[52] Larson, T.E., Buswell, A.M., Ludwig, H.F. and Langelier, W.F., 1942. Calcium carbonate saturation index and alkalinity interpretations [with discussion]. Journal (American Water Works Association), 34(11), pp.1667-1684. https://doi.org/10.1002/j.1551-8833.1942.tb17295.x

[53] DeMartini, F.E., 1938. Corrosion and the Langelier calcium carbonate saturation index. Journal (American Water Works Association), 30(1), pp.85-111. https://doi.org/10.1002/j.1551-8833.1938.tb19529.x

[54] Handbook for Operation of Water Treatment Works. The Water Research Commission. The Water Institute of Southern Africa. Frik Schutte March 2006.

[55] Frayne, C., 1999. Cooling water treatment: Principles and practice. New York: Chemical Publishing Company.

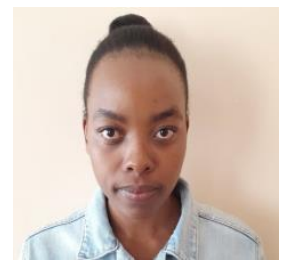

The corresponding author was born in Soweto Gauteng and raised in the rural of North west, currently employed as a Senior Chemist at Komati Power Station at the Chemical Services Department.

She holds:

- Bachelor's degree in Chemical Engineering from the University of Johannesburg

- Honors Degree in Water Utilization Engineering from the University of Pretoria

- Commissioning Engineer Certification under the KWS (KRAFTWERKSSCHULE E.V.) from Germany in 2015

- $\quad$ Project Management Certificate from North West University

She joined Eskom 2008 as a Graduate in training (GIT) after leaving National Chemical Product (NCP) as a process controller to embark on a new journey. She was appointed December 2008 at Chemical Services as a Water Treatment Plant Senior Shift Supervisor. She pursued her career and joined the Commissioning Engineer's program in 2013. Returned from the program 2015 and was promoted to the Senior Chemist position for Water Treatment Plant at the Chemical Services Department as off May 2015 to current.

She was delegated to be the Acting Chemical Services Manager as off October 2016 to January 2019. This included standing in for the Operating Manger for Komati. The department was nominated and awarded for station best performer of the year under the excellence category for Komati in 2017. She has mentored and supervised students in Komati, and currently a student and being mentored herself under Eskom Power Plant Engineering Institution (EPPEI).

Lungile is very passionate about her work and always striving for growth and empowerment, currently busy with a Master Degree in Chemical Engineering at North West University in Potchefstroom. 